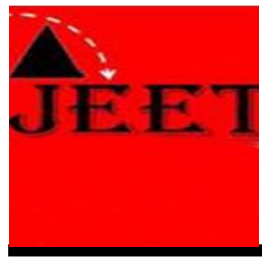

\title{
A Study of Systemic Functional Linguistics: Political Ideology of Donald Trump and Hillary Clinton in First Presidential Debate
}

\author{
Alda Fitriani Suwandi \\ Universitas Airlangga \\ aldasepuluh9@gmail.com \\ Muhammad Thoriqussuud \\ UIN Sunan Ampel \\ thoriqussuud@uinsby.ac.id
}

Corresponding email: aldasepuluh9@gmail.com

\begin{abstract}
This journal article discusses how to reveal the ideology through two approaches, those are transivity process by MAK Halliday and the theoritical framework in Critical Discourse Analysis by Fairclough. This journal article investigates Donald Trump and Hillary Clinton ideology, then compares their ideology who is more prominent. Before revealing their ideology, the researcher compares the transivity process of both candidates and finds that Donald Trump has 281 clauses consist of transivity process, while Hillary Clinton has 203 clauses consist of transivity process. The differences of the total numbers of transivity process, it also reflects to the tendency of ideology. It has shown that Trump has $60 \%$ to the citizen involvement rather than Hillary has $52 \%$. Then, in the aspect of national priority, Hillary has the highest tendency that is $16 \%$ rather than Trump has $6 \%$. The third aspect is policy of law Hillary also has the highest tendency that is $11 \%$ than Trump only $7 \%$. In the aspect of equality in democracy ideology, Trump gets $7 \%$ while Hillary gets $0 \%$. In the last aspect, is national unity Trump gets $20 \%$ tendency than Hillary gets $19 \%$. Finally, the researcher concludes that Donald Trump's ideology is the most prominent than Hillary Clinton.
\end{abstract}

Keywords: Fairclough's Therotical Framework; Ideology; Systemic Functional Linguistics; Transivity Process

\section{Introduction}

Political campaign is one of tranding topics nowadays which attempt to many reseachers to conduct as their study. Study about political campaign is really important because the reader will know about the ideology of the candidates. So that the previous studies are conducted by different perspective such as communication, language.

Conducting the research through language, one of approach is Sistemic Functional Linguistics that is an interesting theory used by many researchers to investigate the study nowadays. The Sistemic Functional Linguistics (SFL) developed by M.A.K. Halliday in 1960 and focuses on language and the function of grammar. It engages the approach of language which uses to demistify the reality and legislate 
in social relationship. So that, this theory declare the functional of language. The meaning of functional of language, that language is a resource to create the meaning. There are three component of functional or named "metafunctions", those are textual, interpersonal, and experential.

Moreover, to reveal the ideology using SFL, the researcher focuses on transivity process is branch of experential metafunction. Cited (Halliday, 2004) There are some types of transivity process those are, first, material process means a process of doing and happening. The notion of material process are actor and goal. Actor is the doer of an action, while goal is the entity leads the process. Second, mental process means a process of sensing. Cited to Halliday $(2004,197)$ " This process of sensing may be construed either as flowing from a person's consciousness or as impinging on it...". there are two properties in mental process those are senser, which the one who able to 'sense' (feels, thinks, etc), while another one is phenomenon which is something is felt, thought, wanted, or perceived. The sensing in mental process is distinguish into some types based on Halliday $(2004,208)$, those are perceptive (see, feel, taste, smell, hear, etc), cognitive (think, believe, understand, consider, expect, etc), desiderative (want, wish, hope, refuse, comply, etc) and emotive (like, fancy, love, hate, dislike, etc).

Next, behavioral process, is the typically of human which refers to psychological behavior physiological such as smiling, dreaming, etc. In behavioral process there is behaver as behave of entity, but if there is second enity it called behavior. Fourth, relational process is a configuration of 'being'. There are three principles of relational process, those are intensive, possesive, and circumtantial. Attributive and identifying are kinds of mode which appears in all principles of relational process. Attributive has some characteristics cited (Halliday, 219) there are attribute which entity has some class then labeled, and carrier that the entity is ascribed. Whereas identifying, the characteristics cited Halliday $(2004,227)$ "Structurally we label the x-element, that which is to be identified, as the identified, and the a-element, that which serves as identity, as the identifier".

Fifth, verbal process is process of saying. In verbal process, the important one of component is the participant that speak, it called sayer. Furthermore, there are three functions of participant to the sayer, first is receiver someone to whom saying 
directed for example me, your parent, etc. Second is verbiage means the topic of saying. Third is, target means the entity become a target of saying. Last, exintential process means a process of doing and happening or the entity exist or happens. The term existent in existential process means the entity is being said to exist.

This theory has developed by many researchers who conducted transivity process as their reseach. For the examples Cunanan (2011) and Song (2013) has applied in novel and short story; Miranti (2014) and Anashia (2016) transivity process also success conducted in newspaper by; Isti' anah (2014) and Yujie \& Fengjie (2018) conduct this theory in politician speech; Khairun (2013) and Salsabil (2014) applied transivity process to analyze the english book; Zhang (2017) transivity process has applied in debate.

Furthermore, ideology is very important aspect to establish and maintain an unequal power relations. Ideology according to Thompson (1990), "is the ways in which meaning is constructed and conveyed by symbolic forms of various kinds" same as Eagleton (1994), study about ideology has consider variation of theories and the theorist which have examined the link between thought and social reality. So that study of ideology also investigate the context of social with the form of symbolic that are employed and deployed. The political Ideology is differs from ideology. Political ideology according Sargent (1981:3) is an ideology that focuses on the political. There are some kinds of political ideologies, such as nationalism, democracy, communism, anarchism, liberalism, conservatism, enviromentalism, capitalism, socialism, and islam.

Moreover, to reveal the ideology researcher combines with theoritical framework in CDA by fairclough. The theoritical frameworks in CDA from Fairlough can be applied which is there are three stages of analysis in CDA (Fairclough, 1989) those are description, interpretation and explanation. Many researchers have been conducted about ideology such as Darweesh \& Kamel (2016) in news report; Anggit (2013) and Zheng (2015) in politician speech.

Related to this research, the present researcher provides some previous study to support this research. First, Yujie \& Fengjie (2018) conducted the study about transivity process used by Donald Trump's inaugural address. The result of their study is all the six types of transivity process are occured in Trump's speech which is $64,67 \%$ 
is material process, $14,92 \%$ is relational process, $11,94 \%$ is mental process, $2,48 \%$ are verbal process and existential process, and last $3,48 \%$ is behavioral process. The material process is the most used by Trump's by the aim to emphasize that American become a ruler and the goverment also controlled by American. This research only analyzed about the transivity process whitout any explanation of Trump's ideology. Moreover, Anggraini (2018) has conducted the study by combining transivity process and CDA as approach to revealing ideology. She used Donald Trump's as the object of research. Then, as the result of her studies is all the types of transivity process occured in Trump's speeches, those are 52\% is material process, $9 \%$ is mental process, $25 \%$ is relational process, $4 \%$ is behavioral process, $8 \%$ is verbal process, and $2 \%$ is existential process. Then, all those result of transivity process intrepets as Trump's ideology which are put himself forward as the national unity, put the equality among the citizens, put the citizens as determiner to make decision, and put the Americans as the priority. In the other hand, we can conclude that Trump follows democracy ideology. This research only focuses on Trump's ideology, without compare his opponent, Hillary Clinton.

Furthermore, Zhang (2017) successed conduct the research by compairing Donald Trump and Hillary Clinton about their transivity process in a debate. As the result Donald Trump's transivity process are $35,06 \%$ is meterial process, $18,18 \%$ is relational process, $15,58 \%$ is mental process, $12,99 \%$ is exixtential process, $11,69 \%$ is verbal proccess, and $6,49 \%$ is behavioral process. Whereas, Hillary Clinton's transivity process are $37,66 \%$ is material process, $28,57 \%$ is mental process, $24,68 \%$ is relational process, $5,19 \%$ is verbal process, $2,60 \%$ is exixtential process, and $1,30 \%$ is behavioral process. This research only focused on the transivity process of both candidate. The research does not reveal their ideology in the debate.

Finally, all of the previous studies above do not cover the gap. The first previous study only focuses on Trump's transivity process without consider his ideology. Whereas, the second previous study has covered the gap, which is the finding reveals Trump's ideology through transivity process. It still has missing, which the researcher does not discuss Trump's opponent, Hillary which both of them are the candidate of US president. The last previous study the researcher has been success to compare Donald Trump and Hillary Clinton transivity process in debate. 
But, this previous study did not analyzed the ideology of them, so that the result still missed and need to be explored.

Therefore, the present researcher will combine two different approaches in linguistics those are transivity process and CDA and applied in political debate campaign between Donald Trump and Hillary Clinton. This debate is chosen as an object since both of them were the candidates of United States president which campaigning. This object is relevant with the aim of this study which is to see whose ideology is most prominent. Last, the researcher hopes that the findings in this research, can be a good reference for readers especially for linguistics learners.

\section{Research Methodology}

The research design used in this study will use descriptive- qualitative. Accroding to Ary (2010), descriptive qualitative elaborate the data which in the term of pictures or words, instead of numbers and statistics. This present study, will use descriptive as a method because this method able to investigate the types of transivity process which found in the debate and able to reveal the ideology of both US president candidates. The instrument of this research is the first presidential debate of Donald Trump and Hillary Clinton video which taken from NBC News Channel on YouTube. The present researchers decided to choose this channel on YouTube since it provides the full version of presidential debate video.

Moreover, there are several steps in collecting and analyzing the data used by the researchers those are searched and downloaded the video, then transcripted the video since it was the easiest way to analyze the data. Next is identifying, classifying, analyzing the data and making a conclusion at the end of this research. In Identifying the data, after the researchers transcripted the speech, the researchers identified the transivity process such as material process, mental process, relational process, behavioral process, verbal process, and existential process in both of presidential debate's speech. Every speech which has contain transivity, was highlighted in different colours and was given by different codes. See the table below. 
A Study of Systemic Functional Linguistics: Political Ideology of Donald Trump and Hillary Clinton in First Presidential Debate

Table 1 : Codes and Highlight of types of Transivity Proces

\begin{tabular}{|c|l|c|l|}
\hline No. & Types of Transivity Process & Transivity Codes & Highlight Colours \\
\hline 1 & Material Process & MaP & \\
\hline 2 & Mental Process & MeP & \\
\hline 3 & Relational Process & BP & \\
\hline 4 & Behavioral Process & RP & \\
\hline 5 & Verbal Process & VP & \\
\hline 6 & Existential Process & EP & \\
\hline
\end{tabular}

Next step is classifing data that the researchers classified transivity process of Donald Trump and Hillary Clinton into classification table. The term of table was shown below.

Table 2 : Classification of Donald Trump and Hillary Clinton's Transivity Proses

\begin{tabular}{|c|c|c|c|c|c|c|c|c|c|c|c|c|c|c|c|}
\hline \multirow{3}{*}{ No } & \multicolumn{7}{|c|}{ Donald Trump } & \multirow{3}{*}{ No } & \multicolumn{7}{|c|}{ Hillary Clinton } \\
\hline & \multirow{2}{*}{ Data } & \multicolumn{6}{|c|}{ Types of Transivity } & & \multirow{2}{*}{ Data } & \multicolumn{6}{|c|}{ Types of Transivity Process } \\
\hline & & MeP & MaP & BP & RP & VP & EP & & & MeP & MaP & BP & RP & VP & EP \\
\hline & & & & & & & & & & & & & & & \\
\hline & & & & & & & & & & & & & & & \\
\hline \multicolumn{2}{|c|}{ Total } & & & & & & & \multicolumn{2}{|c|}{ Total } & & & & & & \\
\hline \multicolumn{2}{|c|}{ Total of Transivity } & & & & & & & \multicolumn{2}{|c|}{ Total of Transivity } & & & & & & \\
\hline
\end{tabular}

From the table above, it will be shown how many types of transivity proces that have both of candidates. The column of data was filled by the transcript of the speech, while in the types of transivity process column were filled by the minute that the speech taken. After that, the researchers counted all the transivity process. Then, those numbers changed into percentage and shown into comparison pie charts (Donald Trump and Hillary Clinton's pie chart), so that it will be easy to understand. The examples of comparison of pie charts were shown below. 

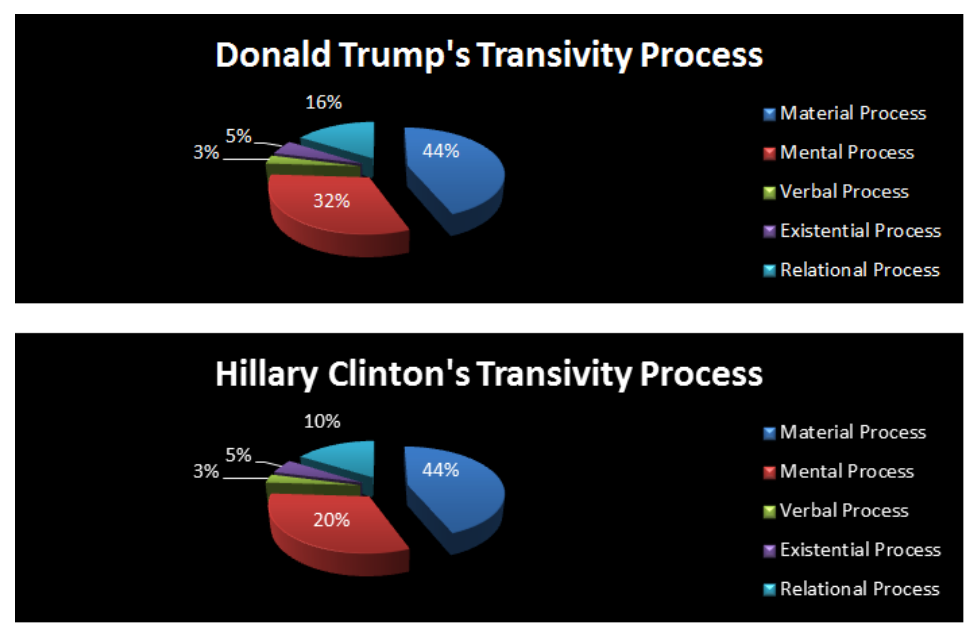

Figure 1. Donald Trump Transivity Process

Those findings above were put in the findings part in this research. After comparing the transivity process of each candidates, the researchers interpreted into their ideology using the ideology classification table. This table consisted of the elements of ideology which they follow. The classifications of element of ideology is shown in the table below.

Table 3 : Classification of Donald Trump and Hillary Clinton's Ideology

\begin{tabular}{|c|c|c|c|c|c|c|c|c|c|c|c|}
\hline \multirow[b]{3}{*}{ No } & \multicolumn{5}{|c|}{ Donald Trump } & \multirow[b]{3}{*}{ No } & \multicolumn{5}{|c|}{ Hillary Clinton } \\
\hline & \multirow[b]{2}{*}{ Data } & \multicolumn{4}{|c|}{ Elements of Ideology } & & \multirow[b]{2}{*}{ Data } & \multicolumn{4}{|c|}{ Elements of Ideology } \\
\hline & & $\begin{array}{c}\text { National } \\
\text { Unity }\end{array}$ & Equality & $\begin{array}{c}\text { Citizen } \\
\text { Involvement }\end{array}$ & $\begin{array}{l}\text { National } \\
\text { Priority }\end{array}$ & & & $\begin{array}{c}\text { National } \\
\text { Unity }\end{array}$ & Equality & $\begin{array}{c}\text { Citizen } \\
\text { Involvement }\end{array}$ & $\begin{array}{l}\text { National } \\
\text { Priority }\end{array}$ \\
\hline & & & & & & & & & & & \\
\hline \multicolumn{2}{|c|}{ Total } & & & & & \multicolumn{2}{|c|}{ Total } & & & & \\
\hline
\end{tabular}

Last, the present researchers explained both presidential candidates's ideology based on the comparison ideology pie chart. Then, the present researchers also showed who has prominent ideology from both presidential candidates. Those explanations were put in the discussion part in this study.

All of those steps above can be concluded that the present researchers used Fairclough's theoritical approach in CDA which is contain three stages description, interpretation, explanation. The first stage, description, the researcher identified and classified the transivity process of both the candidates in the debate first. Then, the researcher described all of the transivity process of both candidates. Next stage, interpretation, the researcher interpreted into the ideology that both of candidates followed. Last, the researcher explained how they followed the ideology. Besides, to 
know who has prominent ideology, the researchers provided 2 comparison pie charts. Finally, the researchers made a brief conclusion of the whole result in this study.

\section{Findings and Discussion}

Findings

\section{Comparison of Donald Trump's and Hillary Clinton's Transivity Process}

In this debate the researchers found different of total numbers of transivity process in both of candidates. Donald Trump produced 281 clauses contain of six types of transivity process, whereas Hillary Clinton produced 203 clauses contain of six types of transivity process. The finding of this transivity process shown chart below.

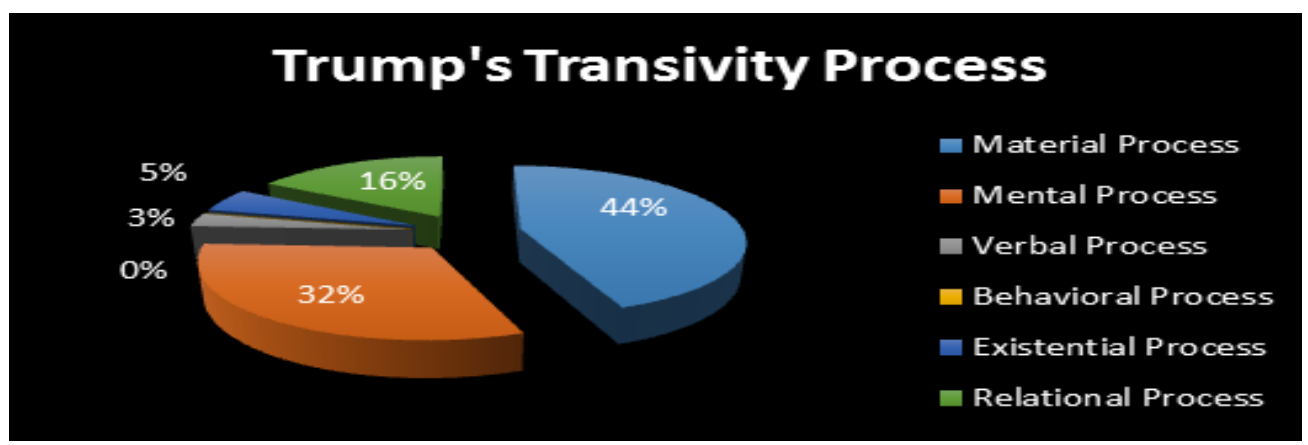

Figure 2. Donald Trump Transivity Process

\section{Hillary's Transivity Process}

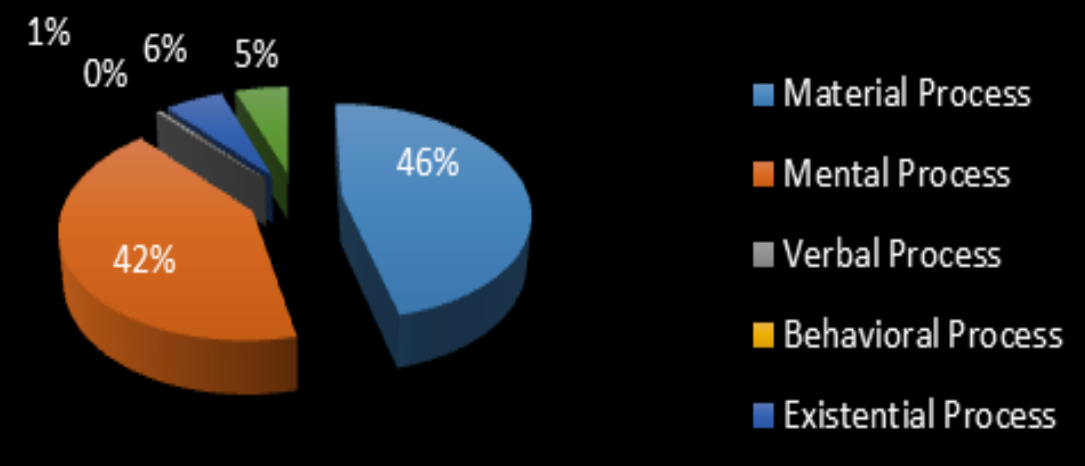

Figure 3. Hillary Clinton Transivity Process

From the depiction of pie charts above, the researchers compare the transivity process which is produced by both candidates, that Trump produced $44 \%$ 
material process and Hillary produced $46 \%$ in material process. The second transivity process is mental process which both of candidates have produced different percentage. Trump gets $32 \%$ while Hillary gets $42 \%$. Furthermore, in verbal process Trump gets $3 \%$ and Hillary gets only $1 \%$. Next, behavioral process does not found in this debate, so that the precentage is $0 \%$ for both of candidates. Exixtential process appear in their speech when having debate but the differences is not too significance. Trump get $5 \%$ while Hillary gets $6 \%$. The last is relational process, Trump gets $16 \%$ and Hillary gets $5 \%$. Finally, the conclusion is Trump has more produced the transivity process rather than Hillary. It is caused Trump trying to dominance than his opponent, Hillary Clinton by more interupting and speaking than Hillary.

\section{Comparison of Donald Trump's and Hillary Clinton's Ideology}

To reveal the comparison of both candidates, the researchers used Fairclough's theoritical framework as an approach in Critical Discourse Analysis. The first stage is description stage where the researchers show the comparison of each transivity process that is used by the candidates. Then, the second stage is interpretation stage where the researchers interpret all of the result of each transivity process used by the candidates to classify their idelogy. The last step is explanation stage, where the researchers explain deeply about the ideology followed by both of candidates and also compare their ideology, whose more prominent.

\section{Description Stage}

Material Process

Material process is the process of doing which is used by the candidates. From Hillary Clinton, she uses the material process as her acts to achieving prosperity in America .

Data 1

We have to build an economy that works for everyone (Hillary, 06:15)

From the data above, Hillary states that to achieve the American prosperity, Hillary and the citizen of America have to build their economy. It is quoted by the modal have to means the action of Hillary and citizen of America to do it and the word build is the specific act that Hillary and citizen of America do.

Data 2 
I want us to do more to support people who are struggling to balance family and work (Hillary, 07:03)

According to the data above, Hillary states we as a citizen of America have to support other people who struggling to achieve their prosperity. Hillary states the word support means the act that Hillary and the citizen of America do to support each other.

Data 3

We're going to enforce the trade deals we have (Hillary, 08:59)

The data above states that Hillary's to achive America prosperity by inviting the citizen to enforce their trade. Hillary used going to as a modal refers to the act that Hillary do for the future America. Then, Hillary used the word enforce means emphasizing that it is the best act to achive American prosprerity.

The material process also used by Donald Trump in debate by stating the word stop, protect, treated as an action do by Trump.

Data 4

We have to stop the violence (Trump, 47:59)

According to data above, Trump invite thee citizen of America to do an action that is stopping the violence. By adding the modal have to before the word stop, it refers to the something which they do for the future America.

\section{Data 5}

We have to protect our inner cities because African- American communities are being decimated by crime. (Trump, 48:18)

The data above means Trump invite the citizen of America to protect AfricanAmerican communities which is abolished by crime. By stating the word protect and also the modal have to, it is indicate the action that Trump and citizen do for future America.

Data 6 
You treated him with terrible disrespect (Trump, 1:04:00)

The statement above, Trump refers to Hillary that she is not respect to the President Brack Obama. The word treated is indicate the action done by Hillary to show her disrespect.

\section{Mental Process}

The mental process is the process of sensing. This process always appear when they speech in debate. Mostly, they used some word to indicate the mental process such as, think, remember, etc.

\section{Data 7}

I think I did a great job and a great service not only for the country, but even for the president in getting him to produce his birth certificate. (Trump, 1:01:58)

According to the Trump's statement above, Trump uses the word think means it is kind of the mental process, exactly cognition. It is refers to his tought that he has did a great job.

Data 8

Remember where we were eight years ago (Hillary, 15:03)

According to Hillary's speech, she uses the word remember which is a mental process exactly cognition. It means that Hillary remind the citizen of America to remember the tragedy in eight years ago.

Relational Process

Relational process is the process to describe, define, and identify something. This transivity process, appear in some utterances in this debate Data 9

Barack Obama is a man of great dignity (Hillary, 1:03:54)

The satement above, Hillary uses relational process to describe Barack Obama as the previous president of United States. There is to be is means as a predicate of Barack Obama who a man of great dignity.

Data 10

It is a huge problem (Trump, 1:11:07) 
According to statement above, Trump describe that cyber hack is the huge problem faced by American. The word it refers to the cyber hack and is as a predicate to explain the cyber hack that is a huge problem.

Verbal Process

Verbal process is one of the transivity process which is the process of saying. It is used by both of candidate such as in data 11 .

Data 11

I said they do not focus on terror (Trump, 1:18:02)

The statement above, Trump directly said to the citizen of America that he already said to NATO do not focus on the terror. Here, they (NATO) as the receiver of the Trump's message, in which the message is do not focus on terror.

\section{Existential Process}

Existential process, is one of the transivity process which is the prosess of existing or happened. Here, the existential process used to reflect the condition of America, as shown in data 12.

\section{Data 12}

We had the worst financial crisis, the great recession the worst since 1930s. (Hillary,

According to the data above, America had the worst financial in 1930s. By stating the phrase had the worst, means America ever passed this condition. Then, adding the year 1930s, it make this statement stong.

\section{Interpretation Stage}

Citizen Involvement

The citizen have full participation in order to make this goverment running well. The citizen can be consider about the policy which will be apply in America. In this debate, both of candidates, Donald Trump and Hillary Clinton, give the citizen of America to have full participation in order to make this goverment running well. Both of the candidates invite the citizen to help the goverment. 
Data 1

We also have to make the economy fairer. (Hillary, 06:42)

Here, Hillary invite the citizen of America to help the goverment make the economy fair. She add the citizen as a part of the goverment who has full participation. Same like Hillary, Trump also involve the citizen to help the goverment programe like in data 2

\section{Data 2}

We have to stop jobs from being stolen from us. We have to stop our companies from leaving the United States and within it firing all of their people. (Trump, 09:27)

The statement above describe that Donald Trump also put the citizen of America to help the goverment. Moreover, the citizen help the goverment to keep the job in America, to keep themselves to work in America. Then, the citizen also help the goverment to support the companies stay in America.

\section{National Priority}

National priority means the America put the number one. The citizen of America is the goal to make America better. Both of candidate have put America as their priority, like in the data 3.

\section{Data 3}

The more we can invest in you, your education, your skills, your future the better we will be off and we'll grow better. (Hillary, 11:53)

The statement above means that Hillary put the citizen America by word you as her priority. Hillary invest everything fo the citizen such as education, skill to make America life better. Also Donald Trump, put the citizen of America as his prioty, like in data 4.

\section{Data 4}

We have to do a much better job at giving companies incentive to build new companies or to expand. (Trump, 18:30) 
Trump's statement refers to the citizen of American who have a company. Trump put them to make their company stay in America by giving incentive to expand their company. So that, they will need more employee and another citizen of America will have a job in America. The citizen of America will get a better job in here. And finally, the economy growth better.

\section{A Policy of Law}

In this debate, the candidates Trump and Hillary try to make a policy in which make America better. Both of them have a brilliant policy to make the economy of America growth better. Besides, the policy also make citizen of America life better.

\section{Data 5}

We also have to make the economy fairer, that starts with raising the national minimum wage and also guarantee. Finally, equal pay for women's work. (Hillary,

\section{6:46)}

The statement above, Hillary makes a policy of law to the economy fairer. Her policy is start from raising the national minimum wage and guaratee. This policy really make the citizen of America as the priority. Hillary put the America to have a better life. Then, hillary also make a policy about equal pay. Whether it is man or women, Hillary's policy is giving equal wage for them, whether it is women. So that, women's work also gets a better life. Almost same with Hillary, Trump also has a policy for America .

\section{Data 6}

My plan, l'll be reducing taxes termendously from $35 \%$ to $15 \%$ for companies small and big businesses. (Trump, 09:47)

According to the statement above, Trump makes a policy for the citizen of America who has company. Trump will reduce the taxes for companies, so that the company will still stay in America because of low taxes. The aim of Trump's policy is to make the economy growth better because the compannies stay in America. Equality

In democracy ideology, the politicians must consider the equality for all the citizen. In this debate, there is a point which discuss about the equality of the citizen. Trump has declare that he want to make all of American same, whether they are African- American, or moslem, they will be protected by the goverment and give 
the guarantee that there is no any discrimination. Quoted from Trump's speech in data 7.

Data 7

No discrimination against African- American, againts muslims, againsts anybody.

(Trump, 1:04:04)

Trump's statement above, refers to the all of citizen of America is same. No matter they are African- American or they are muslims, they will get guarantee in America that there is not any discrimination anymore.

National Unity

National unity means the citizens become a single part of one nation. So that, all of the citizen will have same feeling, same stuggle to make their country better. Both of the candidates become the unity of nation. Indeed, they have same struggle to make America better.

Data 8

We had the worst financial crisis, the great recession the worst since 1930s. (Hillary,

According to the Hillary Statement above, she used the word we which refers to all of the citizen of America include herself as one nation. It is also refers that Hillary and the citizen of America have same condition when America has worst financial in 1930s. Donald Trump also put himself as the national unity, according to his speeches in data 9,

Data 9

Our country's in deep trouble. (Trump, 10:00)

According to the Trump's statement, Trump and also the citizen of America belong to this country. They are the owner of this country. So that, by saying our, it refers that they are the one who feel this country in deep trouble.

\section{Explanation Stage}

The result of two stages before, the researcher compares their ideology which is shown in chart below. 


\section{Trump's Democracy Ideology}

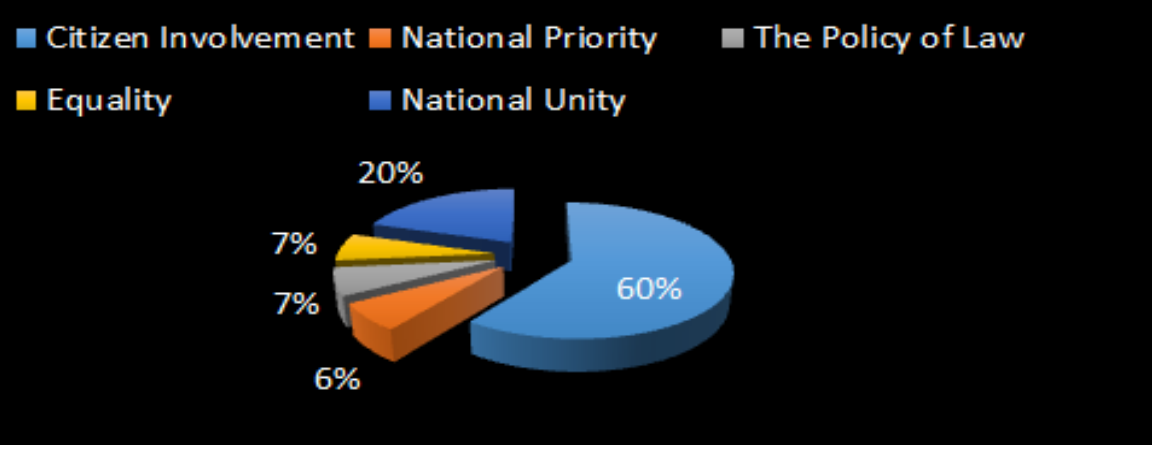

Figure 4. Donald Trump Democracy Ideology

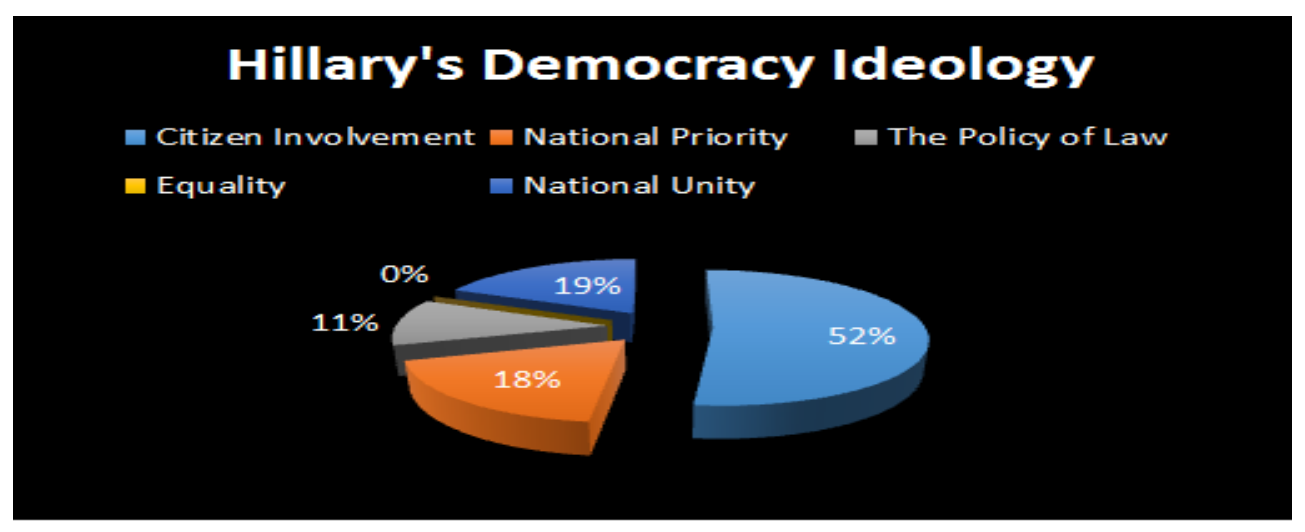

Figure 5. Hillar Clinton Democracy Ideology

From the pie chart above, researcher compares the ideology of both the candidates which more prominent. Both Donald Trump and Hillary Clinton follow democracy ideology. There are some aspects of democracy ideology which researcher found, those are citizen involvement, national priority, a policy of law, equality and national unity. The result show that in every aspect, the candidates have different tendency. In the citizen involvement aspect, Hillary Clinton gets $52 \%$ while Donald Trump gets $60 \%$. It means that Trump more involve the citizen of America to help the goverment in every problem, so that the citizen able to realize America better than before. In the second aspect, the national priority of Hillary Clinton has 18\%, whereas Donald Trump has $6 \%$. It is explained that Hillary put the America as her priority rather than Donald Trump. It has proven by Hillary's speech "The more we can invest in you, your education, your skills, your future the better we 
will be off and we'll grow better." Hillary want to make American more educated, more ability so that their life will be better.

Furthermore, the third aspect of democracy ideology is about the policy of law. Hillary Clinton gets $11 \%$ and Donald Trump gets $7 \%$, it means that Hillary has some new policies in economy where it will make economy of America growth. Quoted from Hillary speeches that "that starts with raising the national minimum wage and also guarantee. Finally, equal pay for women's work." From her planning of new policy, Hillary really forces economy of America by doing that. Contrast with the fourth aspect of democracy ideology, that is equality, Donald Trump gets $7 \%$ while Hillary Clinton gets $0 \%$. It caused Donald Trump have mentioned that there is no any discrimination again, by the proof "No discrimination against AfricanAmerican, againts muslims, againsts anybody." Contrast with Hillary Clinton, she does not mention about the equality among the citizen of America.

Last but not least, the fifth aspect of ideology is national unity. National unity is the aspect that as the candidates, both Trump and Hillary are positioning themselves in the same unity like other citizen. They have same feeling about America. Here, Hillary gets $19 \%$ and Trump gets $20 \%$. It is explained that both of them positioning themselves as a citizen of America. The difference of percentage is not too significant, because it is only differ $1 \%$.

\section{Discussion}

In reveling ideology as the purpose of this study, the researchers identified and classified the speech of Donald Trump and Hillary Clinton during the presidential debate first. According to findings above, the researcher found the differences of total numbers of transivity process used by Donald Trump and Hillary Clinton. Donald Trump gets 281 clauses while Hillary Clinton gets 208 clauses. Those total numbers are distinguished into each type of transivity process in the form of percentage. The first type is material process, Trump gets $44 \%$ and Hillary gets $46 \%$. The second type is mental process, Trump gets $32 \%$ while Hillary $42 \%$. The third is verbal process, Trump gets $3 \%$ whereas Hillary gets $1 \%$. Fourth type of transivity process is behavioral process, in this process both of the candidates do not use this type, so that they get $0 \%$. The fifth type is existential process, which Trump gets $5 \%$ and Hillary gets $6 \%$. Last, 
relational process Trump gets $16 \%$ and Hillary gets $5 \%$. All of these results are divided again into some aspects of the ideology that they follow. So that, in every aspect of the ideology that the candidates follow, consist of some types of transivity process. The ideology is very important aspect to establish and maintain an unequal power relations. The political Ideology is differs from ideology. Political ideology according Sargent (1981) is an ideology that focuses on the political. There are some kinds of political ideologies, such as nationalism, democracy, communism, anarchism, liberalism, conservatism, enviromentalism, capitalism, socialism, and islam. In this study, the researcher identifies that both of the candidates, Donald Trump and Hillary Clinton follow democracy ideology. Democracy ideology has several aspects but in this research, researcher only found five aspects in it those are citizen involvement, equality, national priority, national unity, and policy of law. Both of candidates has different tendency in every aspect of ideology.

Based on the percentage of element in democracy ideology, Trump has $60 \%$ to the citizen involvement rather than Hillary has 52\%. It means Trump more involves the citizen of America to make his goverment running well rather than Hillary Clinton. For the example, when Hillary stated "We also have to make the economy fairer (06:42)" Hillary stated "we" means she and all Americans. The sentence "we have to make" shows that Hillary and the goverment asks all the America citizen must participate to help the goverment to create a better economy for America. Besides, Trump also stated "We have to stop jobs from being stolen from us. We have to stop our companies from leaving the United States and within it firing all of their people. 109:27)" which means Trump asks the american to help the goverment to keep the job in America, to keep themselves to work in America. Then, Trump also aks the American to help the goverment to support the companies stay in America. All of the proves above can be concluded that in two data above include in material transivity which is the process of doing (Halliday, 2004) that word "we" in every utterances of Trump and Clinton reflect that both presidential candidates involve American to participate in creating better America together with goverment.

Then, in the aspect of national priority, Hillary has the highest tendency that is $16 \%$ rather than Trump has $6 \%$. It reflects that Hillary always puts Amrica as her priority and make America as the most important. It can be seen that the used of mental 
process in her speeches, for the example "The more we can invest in you, your education, your skills, your future the better we will be off and we'll grow better. (Hillary, 11:53)". The sentence "we invest you" means we as Hillary and the goverment want to invest all Americans "you" to get the better life such as American's skills, education and so on. Besides, Trump speeches also contain material process to show his act which make America as his priority. For example, "We have to do a much better job at giving companies incentive to build new companies or to expand. (Trump, 18:30)". The word "companies" means American's companies that the goverment hopes they can expand or build new companies. Then, Trump said "giving companies incentive" means Trump gives incentive to help American's companies expand their bussiness. Thus, Trump makes American as his priority. Moreover, it can be concluded that both presidential candidates make American as their priority as Sargent (1981) said that the America is the number one and the goal to make America better. All are reflected in the material process as the process of doing (Halliday, 2004) by saying "invest, giving" as the form of their action.

The third aspect is a policy of law. Hillary also has the highest tendency that is $11 \%$ than Trump only $7 \%$. It means that Hillary has many new policies to make America better than Trump's policies. For the example, " ...that starts with raising the national minimum wage and also guarantee. Finally, equal pay for women's work (Hillary, 06:46)". Hillary's statement show the material process by saying "starts" which means, Hillary wants to begin the policy of equal payment by rairising the national minimum wage. The word "starts" refers to her action in material process as process of doing (Halliday, 2004) to make a policy. Next, Trump also stated his policy by saying "My plan, I'll be reducing taxes termendously from 35\% to 15\% for companies small and big businesses. (Trump, 09:47)". Trump's statement show the material process when he said "I will be reducing" means that Trump will reduce the taxes as his policy to help American's companies. So, all can be concluded that both presidential candidates deliver their policy which part of democracy ideology and it will be implemented in America.

Furthermore, in the aspect of equality in democracy ideology, Trump gets $7 \%$ while Hillary doest say anything. It caused that Trump mentioned that he does not 
want any discrimination again. For the example "No discrimination against AfricanAmerican, againts muslims, againsts anybody. (Trump, 1:04:04)". Trump's speech shows the existential process means the entity exist or happens (Halliday, 2004). Than, based on Trump's speech, the discrimination exists in America and now, Trump wants to be equal and no discrimination anymore. Since the equality is part of democracy ideology (Sargent, 1981) which means everyone are equal in race, religions and have same rights and obligations.

Last aspect national unity Trump gets $20 \%$ tendency than Hillary gets $19 \%$. Both of the candidates put themselves as the unity of America, since the words "we" are always uttered by Trump and Hillary which means, both the presidential candidates and American to be the one or become a unity. It reflects when the material process appears, the actor "we" refers to the presidential candidates include the America citizen and the goal refers to the better America. Since the national unity is part of democracy ideology which means the rule made by the citizen, for citzen, and from citizen, so, The presidential candidates are also the citizen same as American.

Finally, all of the transivity process has helped the researchers to reveal the ideology of presidential candidates. As stated above that both Trump and Hillary have several elements in democracy ideology such as citize involvement, making policy of law, national unity, equality and national priority. All of those elements consists of several transivity processes, however the researchers can not fix that each element has fix one type of transivity process, which means it can be more than one transivity process in each element or having same type of transivity process in each element. For example in citizen involvement element, the researchers found material process in speaker's utterance. In equality element, the researcher found existential process and so on. Thus, the transivity process as a tool to reveal the ideology of the candidate's utterance in debate, besides Fairclough's theoritical framework. Last but of least, the most tendency of democracy ideology is refers to Donald Trump. Since in every aspect, Trump has higher percentage rather than Hillary Clinton.

\section{Conclusion and Suggestion}


A Study of Systemic Functional Linguistics: Political Ideology of Donald Trump and Hillary Clinton in First Presidential Debate

The political campaign is the one of interesting research nowadays, because as the researcher able to found what ideology that the candidates follow. In this research, the researcher fill the gap from previous studies about ideology used by Donald Trump and Hillary Clinton by compares the ideology of Donald Trump and Hillary Clinton through two approaches. Two approaches that used are transivity process from Halliday and the theorical framework by Fairclough. As the result, the differences of total numbers in transivity process had by the candidates reflect the tendency of ideology. It has shown by the percentage of every aspect in democracy ideology that, Trump has $60 \%$ to the citizen involvement rather than Hillary has $52 \%$. Then, in the aspect of national priority, Hillary has the highest tendency that is $16 \%$ rather than Trump has $6 \%$. The third aspect is a policy of law, Hillary also has the highest tendency that is $11 \%$ than Trump only $7 \%$. In the aspect of equality in democracy ideology, Trump gets $7 \%$ while Hillary gets $0 \%$. In the last aspect, is national unity Trump gets $20 \%$ tendency than Hillary gets $19 \%$. Finally, the researcher conclude that Donald Trump's ideology is the most prominent than Hillary Clinton.

\section{References}

Abdulrahman, W.A. (2016). An Introduction to Halliday's systemic functional linguistics. Journal of the Study of English Linguistics, 4(1), 70- 80. http://dx.doi.org/10.5296/jsel.v4i1.9423

Amoussou, F. \& Ayodele, A.A. (2018). Principles, theories and approaches to critical discourse analysis. International Journal on Studies in English Language and Literature, 6(1), 11- 18. http://dx.doi.org/10.20431/2347-3134.0601002

Anashia, N.O. (2016). Transivity Analysis of newspaper headlines on terrorism attack in Kenya: A case study of Wesgate Mall, Nairobi. International Journal of Humanities and Social Science, 6(9), 77- 85.

Anggit, F.X.N.P. (2013). Critical discourse analysis of Susilo Bambang Yudhoyono. [Unpublished bachelor degree]. Universitas Dian Nuswantoro Semarang.

Anggraini, N. (2018). Transivity process and ideological construction of Donald Trump's Speeches. [Unpublished bachelor degree]. UIN Sunan Ampel Surabaya.

Ary, D., Jacobsm L.C. \& Sorensen, C. (2010). Introduction to research in education. 8th ed. Canada: Wadsworth.

Cunanan, T. B. (2011). Using transivity as a framework in a stylistic analysis of Virginia Woolf's Old Mrs. Grey. Asian EFL Journal. Professional Teaching Articles, (54), 69-79. 
Darweesh, A.D.A. \& Kamel, H.A.E.(2016). Ideology in news report: Al- Jazeera Reporter as representative: A Critical discourse analysis. British Journal of English Linguistics. 4(2), 53- 66.

Faiclough, N. (1989). Language and power. New York: Longman Group.

Fairclough, N. (1995). Critical discourse analysis: The critical study of language. New York: Longman Group.

Halliday, M.A.K. \& Matthiessen, C. (2004). An Introduction to functional grammar. 3rd ed. London: Hodder Arnold.

Isti'anah, A. (2014). Transivity analysis in four selected opinions about Jakarta Governor Election. Phenomena, 14(2), 163-175.

Khairun, M. N. (2013). A transivity analysis of genres in the tenth grade senior high school textbook developing English competencies. [Unpublished bachelor degree]. Universitas Negeri Yogyakarta.

Knupfer, N.N \& MCLellan, H. (2001). Descriptive research methodologies. Handbook of research for educational communications and technology. 1196- 1212.

Miranti, I. (2014). Transivity analysis in the construction of newspaper ideology: A comparative study on the New York Times and the Washington Times' Editorials. [Unpublished bachelor degree]. Universitas Dian Nuswantoro.

Salsabil, S. (2014). A Transivity Analysis of English texts in Bahasa Inggris When English Rings The Bell. [Unpublished bachelor degree]. Universitas Negeri Yogyakarta.

Sargent, L.T. (2009). Contemporary political ideologies: A Comparative analysis. Belmont: Wadsworth.

Schiffrin, D., Tannen, D., Hamilton, H.E. (2001). The handbook of discourse analysis. Oxford: Blackwell Publishers Ltd.

Song, Z. (2013). Transivity Analysis of A Rose for Emily. Theory and Practice in Language Studies, 3(12), 2291- 2295. http://dx.doi.org/10.4304/tpls.3.12.2291$\underline{2295}$

Wodak, R. \& Meyer, M. (2001). Method of critical discourse analysis. London: Sage Publications Ltd.

Yujie, Z. \& Fengjie, L. (2018). Transivity analysis of American president Donald Trump's Inaugural Speech. International Journal of Literature and Arts, 6(2), 28- 34. http://dx.doi.org/10.1 1648/j.ijla.20180602.11

Zhang, Y. (2017). Transivity analysis of Hillary Clinton's and Donald Trump's first television debate. International Journal of Applied Linguistics \& English Literature, 6(7), 65- 72. http://dx.doi.org/10.7575/aiac.ijalel.v.6n.7p.65

Zheng, H. (2015). Classification and ideology: A Critical discourse analysis of Bush's Two Speeches on 911 Attack. World Journal of English Language, 5(1), 48- 55. https://doi.org/10.5430/wjel.v5n1p48 